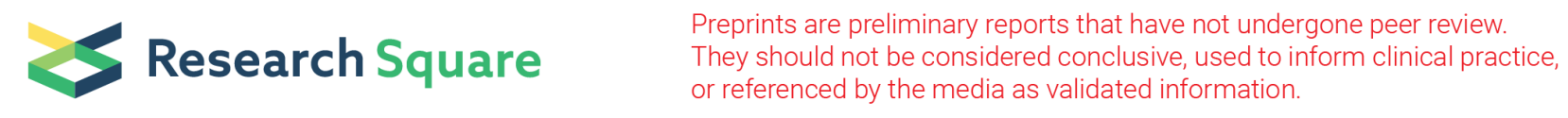

\title{
Protective Effect of Bee Pollen In Acute Kidney Injury, Proteinuria, And Crystalluria Induced By Ethylene Glycol Ingestion In Rats
}

\author{
Asmae Elghouizi \\ Sidi Mohamed Ben Abdellah University \\ Noori Al-Waili ( $\sim$ noori786@yahoo.com ) \\ New York Medical Care for Nephrology \\ Nawal Elmenyiy \\ Sidi Mohamed Ben Abdellah University \\ Salma Elfetri \\ Sidi Mohamed Ben Abdellah University \\ Abderrazak Aboulghazi \\ Sidi Mohamed Ben Abdellah University \\ Ahmed Al-Waili \\ New York Medical Care for Nephrology \\ Badiaa Lyoussi \\ Sidi Mohamed Ben Abdellah University
}

\section{Research Article}

Keywords: Bee pollen, Ethylene glycol, Crystaluria, Cystone, Proteinuria, Acute kidney injury, Liver

Posted Date: December 14th, 2021

DOI: https://doi.org/10.21203/rs.3.rs-1129427/v1

License: (c) (i) This work is licensed under a Creative Commons Attribution 4.0 International License. Read Full License 


\section{Abstract}

Oxidative stress plays a role in hyperoxaluria-induced kidney injury and crystallization. Bee pollen is a hive product with a high content of antioxidants. The antioxidant content and protective effect of bee pollen extract (BPE) against ethylene glycol (EG) induced crystalluria and acute kidney injury (AKI) were investigated. Ten groups of male Wistar rats were treated with EG, cystone $(500 \mathrm{mg} / \mathrm{kg})$ or BPE at doses 100 , 250 , and $500 \mathrm{mg} / \mathrm{kg}$. On day 30, blood and urine samples were collected for analysis. Kidneys were removed for histopathological study. The antioxidant activity of BPE was assessed, and its total phenols and flavonoids were determined. EG significantly increased urine $\mathrm{pH}$, volume, calcium, phosphorus, uric acid, and protein, and blood urea, creatinine, and liver enzymes $(P<0.05)$. It decreased creatinine clearance and urine magnesium and caused crystalluria. Treatment with BPE or cystone mitigates EG's effect; BPE was more potent than cystone $(P<0.05)$. BPE increases urine volume, sodium, and magnesium compared to the control and $\mathrm{EG}$ treated groups. BPE reduces proteinuria and prevents AKI, crystalluria, liver injury, and histopathological changes in the kidney tissue caused by EG. BPE might have a protective effect against EG-induced AKI, crystalluria, and proteinuria, and stone deposition, most likely by its antioxidant content and activity.

\section{Introduction}

$\mathrm{AKI}$ and proteinuria are common and associated with significant morbidity and mortality in the clinical setting, where there is no effective intervention to manage them. EG ingestion increases serum and urine oxalate levels that cause AKI, renal inflammation, and tubular cell toxicity [1.2]. We have found that propolis, a bee product with high antioxidant activity, prevents proteinuria and AKI induced by EG [3]. Other studies showed that EG causes acute liver injury [3-5].

Urolithiasis is a common clinical problem and associated with mineral deposition in the urinary system. It is a multifactorial disorder resulting from the combined influence of epidemiological, biochemical, and genetic risk factors [6]. Therapy includes allopurinol, citrate, cystone, and thiazide diuretics; however, these are not always effective. Hyperoxaluria is the most crucial factor involved in calcium oxalate stone formation $[7,8]$. Increased urinary $\mathrm{pH}$, calcium, phosphate, uric acid, and decreased urinary citrate, magnesium, and volume play a significant role in stone formation [9].

Ethylene glycol (EG) is a synthetic chemical liquid used in almost all radiator fluid products and used as solvent, emulsifier, or surfactant. Ingestion of EG causes renal injury, and exposure to this solvent in industries causes impairment in liver and kidney functions [10, 11]. EG is a metabolic precursor of oxalate, and the oxalate formation starts after 24-72 hours of its administration. It causes severe metabolic acidosis and acute kidney injury [12]

Fresh bee pollen represents the pollen produced in the flowers collected by Apis mellifera honeybees' workers from various floral sources. Bees add sugars from nectar and enriching with their substances, which bind the grains together into small pellets and bring them back to the hive on their wings and legs. Bee pollen is a vital hive product gaining attention as a functional food for human use due to its high content of bio-compounds with health-promoting effects, such as minerals, essential amino acids, antioxidants, vitamins, and lipids [13]. Bee pollen possesses a wide range of phenolic compounds, such as rutin, quercetin, vanillic acid, and protocatechuic acid, and its composition varies according to its botanical and geographic origins $[13,14]$.

Cystone is a well-known polyherbal formulation used to treat urinary tract infection, facilitate passage of kidney stones, and has antilithic activity in traditional medicine [15-17]. It contains nine different types of plant extract [17]. It has a protective effect against experimentally induced urolithiasis in rats [15]. Cystone at a dose of $500 \mathrm{mg} / \mathrm{kg}$ caused a significant reversal of $\mathrm{NaOx}$-induced changes in ion excretion and urinary $\mathrm{CaOx}$ concentration in rats [18]. It was found that cystone (500 and $750 \mathrm{mg} / \mathrm{kg}$ ) for 28 days has a protective activity against hyperoxaluria-induced oxidative stress and calcium oxalate crystal deposition by improving antioxidant status and increasing urine volume [19]. Furthermore, cystone protects against cisplatin-induced nephrotoxicity [20]. A review of 50 clinical studies showed that cystone improved symptoms, increased urine volume, and reduced the stone-forming constituents in urine without significant side effects [21].

Hyperoxaluria compromised antioxidant levels and upregulated inflammatory markers [22]. A recently published review discussed the role of polyphenols in urolithiasis management [23]. In addition to its antioxidant activity, BPE shows an anti-inflammatory effect [24]. Therefore, the present study investigates the impact of BPE on kidney function and its protective effect against EG-induced AKI, crystalluria, proteinuria, and hepatotoxicity. The result was compared with cystone. Also, the antioxidant content and activity of BPE were studied.

\section{Results}

\section{Effect of the interventions on renal function and electrolytes}

Page 2/15 
In EG untreated groups, BPE and cystone did not cause significant changes in serum creatinine, phosphorus, calcium, sodium, and potassium (Table 1 and 2). BPE caused a significant elevation of serum protein and a significant lowering of serum magnesium. EG caused a significant elevation of serum creatinine, protein, magnesium, phosphorus, sodium, and potassium $(P<0.05)$. Concomitant use of BPE or cystone with EG caused a significant lowering of the parameters compared to EG alone; BPE at higher doses was more potent than cystone.

Table 1

Effect of the interventions on blood level of urea, creatinine and protein on day 30.

\begin{tabular}{|c|c|c|c|c|}
\hline Groups & Interventions & Creatinine $\mathrm{mg} / \mathrm{dl}$ & Urea mg/dl & Protein g/dl \\
\hline \multirow[t]{5}{*}{ EG untreated groups } & Control & $0.5 \pm 0.09$ & $33.5 \pm 4.57$ & $4.25 \pm 0.38$ \\
\hline & Cystone & $0.55 \pm 0.09$ & $27 \pm 3.11$ & $4.45 \pm 0.30$ \\
\hline & BPE-100 mg & $0.5 \pm 0.06$ & $23.2 \pm 3.9 *$ & $6.5 \pm 0.74^{\star} \#$ \\
\hline & BPE $-250 \mathrm{mg}$ & $0.55 \pm 0.07$ & $25.3 \pm 4.35$ & $6.2 \pm 0.28^{\star} \#$ \\
\hline & BPE -500 mg & $0.55 \pm 0.09$ & $32 \pm 4.48$ & $6.16 \pm 0.53^{\star} \#$ \\
\hline F/P value & & $0.605 / 0.66$ & $6.86 / 0.000$ & $31.2 / 0.000$ \\
\hline \multirow[t]{5}{*}{ EG treated groups } & EG & $1.17 \pm 0.07 *$ & $47.5 \pm 5.23^{*}$ & $8.55 \pm 0.57 *$ \\
\hline & EG+ Cystone & $0,7 \pm 0.01 \beta$ & $39 \pm 4.64 \beta$ & $7.18 \pm 0.40 \beta$ \\
\hline & $\mathrm{EG}+\mathrm{BPE} 100 \mathrm{mg}$ & $0.9 \pm 0.11 \beta \pi$ & $27 \pm 4.84 \beta \pi$ & $7.3 \pm 0.43 \beta$ \\
\hline & $\mathrm{EG}+\mathrm{BPE} 250 \mathrm{mg}$ & $0.7 \pm 12 \beta$ & $26 \pm 4.01 \beta \pi$ & $6.86 \pm 0.30 \beta$ \\
\hline & $\mathrm{EG}+\mathrm{BPE} 500 \mathrm{mg}$ & $0.6 \pm 0.09 \beta$ & $37.5 \pm 5.77 \beta \pi$ & $6.15 \pm 0.64 \beta \pi$ \\
\hline F/P value & & $34.17 / 0.000$ & $19.34 / 0.000$ & $19.243 / 0.000$ \\
\hline \multicolumn{5}{|c|}{$\star P<0.05$ compared to EG untreated-control group } \\
\hline \multicolumn{5}{|c|}{$\# P<0.05$ compared to EG untreated-cystone group } \\
\hline \multicolumn{5}{|c|}{$\beta P<0.05$ compared to $E G$ treated group } \\
\hline \multicolumn{5}{|c|}{$\pi P<0.05$ compared to $\mathrm{EG}$ treated-EG+ cystone group } \\
\hline
\end{tabular}


Table 2

Effect of the interventions on blood level of electrolytes on day 30 .

\begin{tabular}{|c|c|c|c|c|c|c|}
\hline Groups & Interventions & $\begin{array}{l}\text { Magnesium } \\
\mathrm{mg} / \mathrm{dl}\end{array}$ & $\begin{array}{l}\text { Phosphorus } \\
\mathrm{mg} / \mathrm{l}\end{array}$ & $\begin{array}{l}\text { Calcium } \\
\text { mg/dl }\end{array}$ & Sodium mmol/l & $\begin{array}{l}\text { Potassium } \\
\mathrm{mmol} / \mathrm{l}\end{array}$ \\
\hline \multirow[t]{5}{*}{ EG untreated groups } & Control & $2.49 \pm 0.35$ & $4.20 \pm 0.35$ & $3.22 \pm 0.41$ & $149.5 \pm 7.11$ & $5.7 \pm 1.44$ \\
\hline & Cystone & $2.68 \pm 0.34$ & $4.28 \pm 0.31$ & $3.45 \pm 0.44$ & $146 \pm 3.89$ & $4.98 \pm 1.16$ \\
\hline & BPE-100 mg & $1.79 \pm 0.20 \star \#$ & $4.20 \pm 0.47$ & $3.46 \pm 0.35$ & $147 \pm 6.72$ & $4.92 \pm 1.3$ \\
\hline & BPE -250 mg & $1.98 \pm 0.23 \#$ & $4.01 \pm 0.29$ & $3.48 \pm 0.46$ & $148 \pm 5.56$ & $5.45 \pm 0.84$ \\
\hline & BPE -500 mg & $1.96 \pm 0.25 \#$ & $4.36 \pm 0.36$ & $3.91 \pm 0.46$ & $145.50 \pm 6.27$ & $5.30 \pm 1.09$ \\
\hline F/P value & & $10.85 / 0.000$ & $0.991 / 0.430$ & $2.23 / 0.092$ & $0.423 / 0.790$ & $0.45 / 0.769$ \\
\hline \multirow[t]{5}{*}{ EG treated groups } & EG & $3.35 \pm 0.50 *$ & $8.55 \pm 0.64^{\star}$ & $8.55 \pm 0.43^{\star}$ & $182.50 \pm 7.14^{\star}$ & $10.75 \pm 2.18^{*}$ \\
\hline & EG+ Cystone & $3.02 \pm 0.45$ & $5.02 \pm 0.34 \beta$ & $6.92 \pm 0.49 \beta$ & $152.72 \pm 5.33 \beta$ & $4.39 \pm 0.44 \beta$ \\
\hline & $\mathrm{EG}+\mathrm{BPE} 100 \mathrm{mg}$ & $2.58 \pm 0.45$ & $6.55 \pm 0.52 \beta \pi$ & $7.45 \pm 0.33 \beta$ & $153.50 \pm 5.22 \beta$ & $4.45 \pm 0.62 \beta$ \\
\hline & $\mathrm{EG}+\mathrm{BPE} 250 \mathrm{mg}$ & $2.36 \pm 0.23 \beta$ & $5.20 \pm 0.56 \beta$ & $6.97 \pm 0.32 \beta$ & $150.50 \pm 6.09 \beta$ & $3.95 \pm 0.56 \beta$ \\
\hline & $\mathrm{EG}+\mathrm{BPE} 500 \mathrm{mg}$ & $2.05 \pm 0.38 \beta \pi$ & $4.95 \pm 0.44 \beta$ & $5.70 \pm 0.47 \beta \pi$ & $152.63 \pm 5.22 \beta$ & $3.60 \pm 0.57 \beta$ \\
\hline F/P value & & $10.44 / 0.000$ & $53.81 / 0.000$ & $35.52 / 0.000$ & $41.68 / 0.000$ & $55.911 / 0.00$ \\
\hline \multicolumn{7}{|c|}{${ }^{*} P<0.05$ compared to EG untreated-control group } \\
\hline \multicolumn{7}{|c|}{$\# P<0.05$ compared to EG untreated-cystone group } \\
\hline \multicolumn{7}{|c|}{$\beta P<0.05$ compared to EG treated group } \\
\hline \multicolumn{7}{|c|}{$\pi P<0.05$ compared to EG treated-EG+ cystone group } \\
\hline
\end{tabular}

\section{Effect of the interventions on the liver enzymes}

In EG untreated groups, cystone significantly elevated ALP, while BPE significantly decreased AST and ALP (Table 3). In EG treated groups, EG significantly elevated liver enzymes $(P<0.05)$. The concomitant use of BPE or cystone with the EG significantly ameliorated EG-induced liver enzymes' elevation; BPE was more potent than cystone $(P<0.05)$. 
Table 3

Effect of the interventions on liver enzymes on day 30 .

\begin{tabular}{|c|c|c|c|c|c|}
\hline Groups & Interventions & AST (U/L) & $\operatorname{ALT}(\mathrm{U} / \mathrm{L})$ & ALP (U/L) & GGT(U/L) \\
\hline \multirow[t]{5}{*}{ EG untreated groups } & Control & $89.94 \pm 9.48$ & $9.50 \pm 1.91$ & $144 \pm 6.63$ & $4.2 \pm 1.16$ \\
\hline & Cystone & $91.64 \pm 5.31$ & $10.50 \pm 2.23$ & $167 \pm 7.43^{\star}$ & $5.1 \pm 0.89$ \\
\hline & BPE-100 mg & $89.50 \pm 4.87$ & $11.29 \pm 2.04$ & $145 \pm 4.31 \#$ & $4.0 \pm 0.69$ \\
\hline & BPE -250 mg & $68.11 \pm 3.35^{\star} \#$ & $12.57 \pm 2.44$ & $134.98 \pm 9.88 \#$ & $4.5 \pm 1.09$ \\
\hline & BPE -500 mg & $57.73 \pm 6.1 * \#$ & $12.85 \pm 2.35$ & $122.12 \pm 4.77^{\star} \#$ & $4.3 \pm 0.63$ \\
\hline \multicolumn{2}{|l|}{ F/P value } & $43.99 / 0.000$ & $2.57 / 0.066$ & $35.05 / 0.000$ & $1.535 / 0.222$ \\
\hline \multirow[t]{6}{*}{ EG treated groups } & EG & $165.50 \pm 9.72^{*}$ & $34.97 \pm 4.35^{\star}$ & $196 \pm 11.88^{*}$ & $10.50 \pm 1.66^{*}$ \\
\hline & EG+ Cystone & $98.33 \pm 4.81 \beta$ & $18.50 \pm 3.08 \beta$ & $183.16 \pm 4.87$ & $6.45 \pm 1.29 \beta$ \\
\hline & $\mathrm{EG}+\mathrm{BPE} 100$ & $142.2 \pm 11.77 \beta \pi$ & $19.50 \pm 3.65 \beta$ & $190 \pm 9.21$ & $4.50 \pm 1.22 \beta$ \\
\hline & $\mathrm{mg}$ & & & & \\
\hline & $\mathrm{EG}+\mathrm{BPE} 250 \mathrm{mg}$ & $114.5 \pm 8.6 \beta \pi$ & $14.56 \pm 1.78 \beta$ & $169.90 \pm 6.17 \beta \pi$ & $5 \pm 0.89 \beta$ \\
\hline & $\mathrm{EG}+\mathrm{BPE} 500 \mathrm{mg}$ & $93 \pm 5.03 \beta \pi$ & $13.79 \pm 3.14 \beta$ & $154 \pm 9.25 \beta \pi$ & $4.45 \pm 0.88 \beta$ \\
\hline F/P value & & $79.23 / 0.00$ & $41.67 / 0.000$ & $23.37 / 0.000$ & $25.99 / 0.00$ \\
\hline \multicolumn{6}{|c|}{$\star P<0.05$ compared to EG untreated-control group } \\
\hline \multicolumn{6}{|c|}{$\# P<0.05$ compared to EG untreated-cystone group } \\
\hline \multicolumn{6}{|c|}{$\beta P<0.05$ compared to EG treated group } \\
\hline
\end{tabular}

\section{Effect of the interventions on the urine volume and $\mathrm{pH}$}

In EG-untreated rats (Table 4), BPE and cytosine caused a significant elevation of urine volume on days 15 and 30 as compared to the baseline and the control $(P<0.05)$. BPE caused a significant increase in urinary sodium and chloride and a significant decrease in urinary potassium, which means that BPE has a potassium-sparing effect. In the EG-treated groups, EG caused a significant increase in the urine volume, which was significantly potentiated with the concomitant use of the BPE. In the EG-untreated groups, BPE and cystone increased insignificantly ( $p>0.05$ ) urine $\mathrm{pH}$ in EG untreated rats (Table 4). In the EG-treated rats, EG caused a significant elevation of the urine $\mathrm{pH}$, which was mitigated by the concomitant use of either cystone or BPE. 
Table 4

Effect of interventions on urinary volume and $\mathrm{pH}$

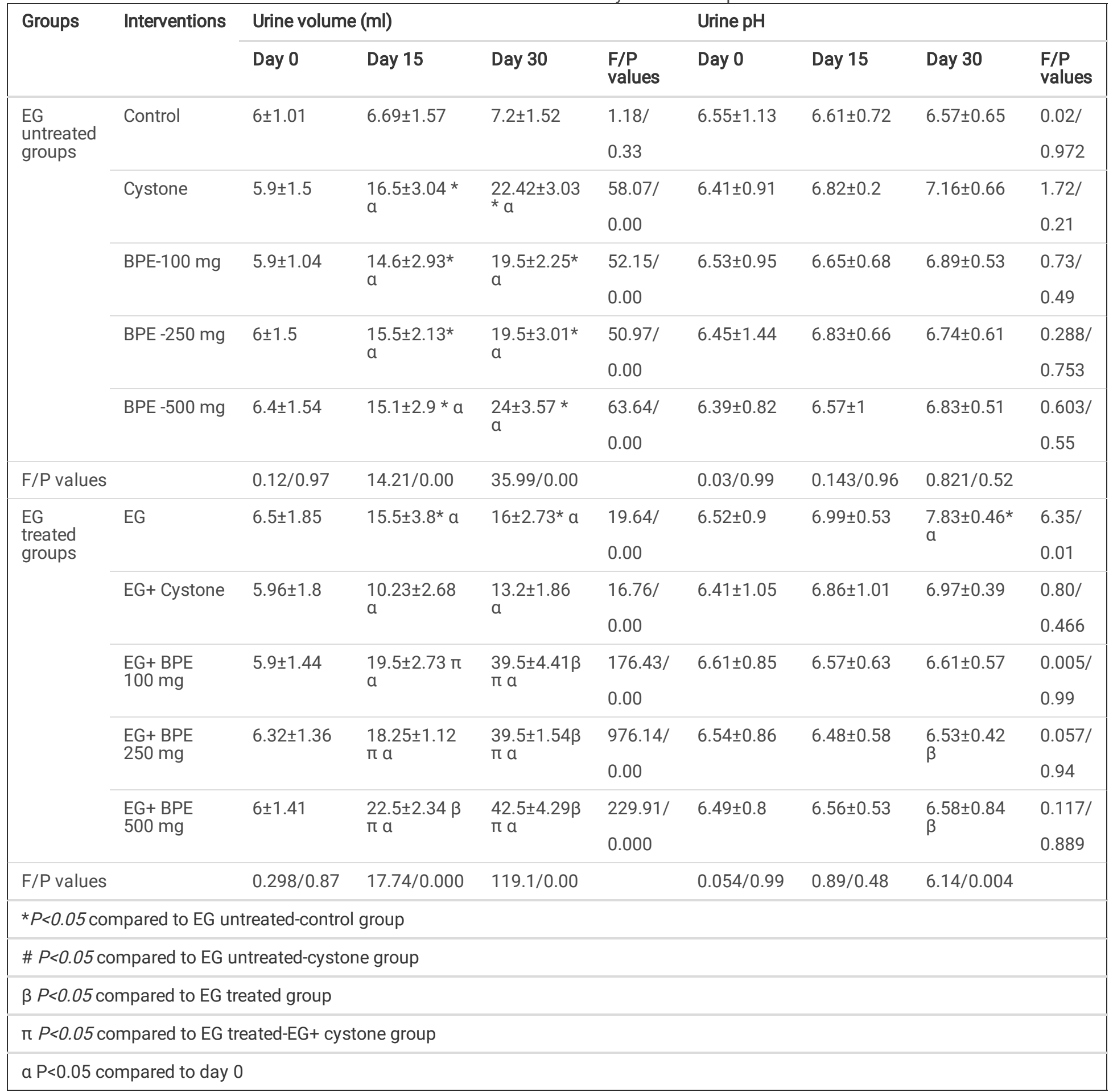

\section{Effect of the interventions on urine calcium, phosphate, and magnesium}

In EG-untreated groups, BPE increased urine magnesium as compared to the control group (Table 5). Cystone does not affect urine calcium, phosphate, and magnesium. In the EG-treated group, EG caused a significant $(P<0.05)$ lowering of urine magnesium and significant elevation of the urine calcium and phosphate as compared to the control group (Table 5). However, treatment with BPE significantly increased urine magnesium and decreased urine calcium and phosphate level when administered with EG compared to the EG-treated group $(P<0.05)$. BPE $(500 \mathrm{mg} / \mathrm{kg} . b . w t)$ has the highest effect on urine magnesium, calcium, and phosphate levels compared to the cystone treated group and the EG-treated group. 
Table 5

Effect of the interventions on urine electrolytes on day 30.

\begin{tabular}{|c|c|c|c|c|c|c|c|}
\hline Groups & Interventions & $\begin{array}{l}\text { Magnesium } \\
\mathrm{mg} / \mathrm{l}\end{array}$ & Calcium mg/l & $\begin{array}{l}\text { Phosphorus } \\
\mathrm{mg} / \mathrm{l}\end{array}$ & $\begin{array}{l}\text { Sodium } \\
\mathrm{mmol} / \mathrm{l}\end{array}$ & $\begin{array}{l}\text { Potassium } \\
\mathrm{mmol} / \mathrm{l}\end{array}$ & $\begin{array}{l}\text { Chloride } \\
\mathrm{mmol} / \mathrm{l}\end{array}$ \\
\hline \multirow{5}{*}{$\begin{array}{l}\text { EG } \\
\text { untreated } \\
\text { groups }\end{array}$} & Control & $268.53 \pm 10.37$ & $120.19 \pm 8.02$ & $53.34 \pm 8.53$ & $146 \pm 10.48$ & $262.50 \pm 16.05$ & $121.50 \pm 11.43$ \\
\hline & Cystone & $281.11 \pm 13.96$ & $119.42 \pm 9.08$ & $49.72 \pm 9.59$ & $243.50 \pm 12.32^{*}$ & $233.50 \pm 13.09 *$ & $287 \pm 12.36^{*}$ \\
\hline & BPE-100 mg & $283.11 \pm 12.81$ & $123.38 \pm 9.13$ & $48.56 \pm 8.48$ & $\begin{array}{l}282.50 \pm 9.35^{\star} \\
\#\end{array}$ & $209.50 \pm 18.32^{\star}$ & $286 \pm 10.03^{*}$ \\
\hline & BPE -250 mg & $286.61 \pm 12.02$ & $119.41 \pm 9.28$ & $49.18 \pm 8.92$ & $389.2 \pm 25.36^{*} \#$ & $211.45 \pm 14.66^{*}$ & $309.50 \pm 15.98 *$ \\
\hline & BPE -500 mg & $290.73 \pm 10.58 *$ & $123.35 \pm 10$ & $53.19 \pm 6.93$ & $391 \pm 29.63^{\star} \#$ & $225.90 \pm 15.76^{*}$ & $304.5 \pm 19.59 *$ \\
\hline \multicolumn{2}{|l|}{ F/P value } & $3.164 / 0.03^{`}$ & $0.309 / 0.888$ & $0.563 / 0.691$ & $180.94 / 0.000$ & $11.79 / 0.000$ & $184.03 / 0.000$ \\
\hline \multirow{5}{*}{$\begin{array}{l}\text { EG treated } \\
\text { groups }\end{array}$} & EG & $136.91 \pm 11.89 *$ & $165.66 \pm 9.51 *$ & $37.77 \pm 8.88^{\star}$ & $32 \pm 9.29 *$ & $163.91 \pm 13.45^{\star}$ & $82.50 \pm 13.76$ * \\
\hline & EG+ cystone & $\begin{array}{l}225.15 \pm 11.48 \\
\beta\end{array}$ & $\begin{array}{l}124.67 \pm 11.16 \\
\beta\end{array}$ & $49.38 \pm 9.57$ & $\begin{array}{l}147.22 \pm 16.53 \\
\beta\end{array}$ & $\begin{array}{l}223.15 \pm 13.95 \\
\beta\end{array}$ & $\begin{array}{l}254.97 \pm 17.52 \\
\beta\end{array}$ \\
\hline & $\begin{array}{l}\mathrm{EG}+\mathrm{BPE} \\
100 \mathrm{mg}\end{array}$ & $\begin{array}{l}185.11 \pm 12.08 \\
\beta \pi\end{array}$ & $\begin{array}{l}155.35 \pm 10.12 \\
\pi\end{array}$ & $\begin{array}{l}69.76 \pm 8.91 \\
\beta \pi\end{array}$ & $132 \pm 12.11 \beta$ & $159.50 \pm 9.81 \pi$ & $\begin{array}{l}126.50 \pm 17.07 \\
\beta\end{array}$ \\
\hline & $\begin{array}{l}\mathrm{EG}+\mathrm{BPE} \\
250 \mathrm{mg}\end{array}$ & $\begin{array}{l}222.23 \pm 11.92 \\
\beta\end{array}$ & $\begin{array}{l}147.29 \pm 10.59 \\
\beta \pi\end{array}$ & $\begin{array}{l}57.94 \pm 11.37 \\
\beta\end{array}$ & $\begin{array}{l}219.5 \pm 17.60 \beta \\
\pi\end{array}$ & $153 \pm 19.15 \pi$ & $176 \pm 15.01 \beta$ \\
\hline & $\begin{array}{l}\mathrm{EG}+\mathrm{BPE} \\
500 \mathrm{mg}\end{array}$ & $\begin{array}{l}234.97 \pm 13.77 \\
\beta\end{array}$ & $122 \pm 8.86 \beta$ & $50.45 \pm 9.32$ & $\begin{array}{l}223.5 \pm 15.17 \beta \\
\pi\end{array}$ & $\begin{array}{l}176.40 \pm 13.59 \\
\pi\end{array}$ & $\begin{array}{l}287.39 \pm 14.80 \\
\beta \pi\end{array}$ \\
\hline \multicolumn{2}{|l|}{ F/P value } & $70.00 / 0.000$ & $20.72 / 0.00$ & $10.02 / 0.000$ & $183.50 / 0.000$ & $23.00 / 0.00$ & $184.72 / 0.000$ \\
\hline \multicolumn{8}{|c|}{${ }^{*} P<0.05$ as compared to EG untreated-control group } \\
\hline \multicolumn{8}{|c|}{$\# P<0.05$ as compared to EG untreated-cystone group } \\
\hline \multicolumn{8}{|c|}{$\beta P<0.05$ as compared to $E G$ treated group } \\
\hline
\end{tabular}

\section{Effect of the interventions on the Urinary Excretion of sodium, Potassium, chloride}

In EG untreated groups, BPE and cystone significantly increased urine sodium and chloride and decreased urine potassium compared to the control group (Table 5). In the EG treated groups, EG significantly decreased urine sodium, potassium, and chloride $(P<0.05)($ Table 5$)$. However, the concomitant use of BPE or cystone with EG caused a significant increase in the urine sodium and chloride compared to EG treated group. The effect of BPE was dose-dependent and more potent than cystone.

\section{Effect of the interventions on urine creatinine, urea, proteins, uric acid, and creatinine clearance}

In EG untreated groups, the interventions did not cause significant changes in the urine protein, urea, and uric acid (Table 6) but caused a significant elevation in the creatinine clearance $(P<0.05)$; BPE was more potent than cystone. In the EG treated group, EG caused a significant elevation in the urine protein and uric acid and a significant decrease in the urine creatinine and urea and creatinine clearance $(P<0.05)$. The concomitant use of BPE and cystone with EG decreased urine uric and increased urine urea, urine creatinine, and creatinine clearance compared to the EG treated group. Interestingly, BPE or cystone with EG caused a significant lowering in the urine protein, and BPE at a dose of $500 \mathrm{mg}$ was significantly more potent than cystone. 
Table 6

Effect of the interventions on urine proteins, urea, creatinine, and uric acid and on creatinine clearance on day 30.

\begin{tabular}{|c|c|c|c|c|c|c|}
\hline Groups & Interventions & $\begin{array}{l}\text { Protein } \\
\mathrm{mmol} / \mathrm{l}\end{array}$ & Urea mmol/l & $\begin{array}{l}\text { Creatinine } \\
\mathrm{mmol} / \mathrm{l}\end{array}$ & $\begin{array}{l}\text { Uric acid } \\
\mathrm{mmol} / \mathrm{l}\end{array}$ & $\begin{array}{l}\text { Creatinine clearance } \\
(\mathrm{ml} / \mathrm{min})\end{array}$ \\
\hline \multirow{5}{*}{$\begin{array}{l}\text { EG untreated } \\
\text { groups }\end{array}$} & Control & $22.50 \pm 3.84$ & $47.10 \pm 4.11$ & $46.20 \pm 5.47$ & $7.5 \pm 0.9$ & $0.047 \pm 0.012$ \\
\hline & Cystone & $24.50 \pm 3.62$ & $45.53 \pm 4.83$ & $47.07 \pm 4.8$ & $8.20 \pm 1.30$ & $0.138 \pm 0.040 *$ \\
\hline & BPE-100 mg & $\begin{array}{l}19.78 .50 \pm \\
3.12\end{array}$ & $42.62 \pm 5.47$ & $48.98 \pm 4.7$ & $8.89 \pm 1.35$ & $0.134 \pm 0.023^{*}$ \\
\hline & BPE -250 mg & $20.07 \pm 3.83$ & $41.90 \pm 3.48$ & $49.25 \pm 4.31$ & $9.4 \pm 1.3$ & $0.124 \pm 0.031 *$ \\
\hline & BPE -500 mg & $21.78 \pm 3.85$ & $42.96 \pm 4.45$ & $53.40 \pm 4.71$ & $8.32 \pm 1.17$ & $0.165 \pm 0.039 *$ \\
\hline F/P value & & $1.681 / 0.185$ & $1.677 / 0.1867$ & $1.888 / 0.143$ & $2.118 / 0.108$ & $12.424 / 0.00$ \\
\hline \multirow[t]{5}{*}{ EG treated groups } & EG & $45 \pm 3.83^{\star}$ & $26.94 \pm 3.21^{\star}$ & $19.30 \pm 3.86^{\star}$ & $13.75 \pm 1.27$ * & $0.017 \pm 0.002^{\star}$ \\
\hline & EG+Cystone & $32.80 \pm 4.17 \beta$ & $34.33 \pm 3.28$ & $34.80 \pm 5.1 \beta$ & $10.96 \pm 2.14$ & $0.045 \pm 0.008 \beta$ \\
\hline & $\begin{array}{l}\mathrm{EG}+\mathrm{BPE} 100 \\
\mathrm{mg}\end{array}$ & $\begin{array}{l}40.62 \pm 4.84 \\
\pi\end{array}$ & $30.39 \pm 3.75$ & $24.62 \pm 3.41 \pi$ & $10.20 \pm 2.3$ & $0.084 \pm 0.02 \beta \pi$ \\
\hline & $\begin{array}{l}\mathrm{EG}+\mathrm{BPE} 250 \\
\mathrm{mg}\end{array}$ & $34.62 \pm 4.64 \beta$ & $31.09 \pm 3.55$ & $34.62 \pm 4.78 \beta$ & $11.60 \pm 1.83$ & $0.148 \pm 0.041 \beta \pi$ \\
\hline & $\begin{array}{l}\mathrm{EG}+\mathrm{BPE} 500 \\
\mathrm{mg}\end{array}$ & $\begin{array}{l}24.12 \pm 3.89 \beta \\
\pi\end{array}$ & $36.87 \pm 4.75 \beta$ & $40.12 \pm 3.96 \beta$ & $9.70 \pm 1.47 \beta$ & $0.200 \pm 0.037 \beta \pi$ \\
\hline F/P value & & $21.35 / 0.000$ & $5.499 / 0.002$ & $13.58 / 0.000$ & $3.124 / 0.032$ & $47.89 / 0.000$ \\
\hline \multicolumn{7}{|c|}{$\star P<0.05$ as compared to EG untreated-control group } \\
\hline \multicolumn{7}{|c|}{$\# P<0.05$ as compared to EG untreated-cystone group } \\
\hline \multicolumn{7}{|c|}{$\beta P<0.05$ as compared to EG treated group } \\
\hline
\end{tabular}

\section{Urine Microscopy And Kidney Histopathological Study}

EG causes crystalluria as compared to the control groups (Figure 1). However, the concomitant use of BPE or cystone with the EG significantly decreased crystalluria and was resolved using BPE at a dose of $500 \mathrm{mg} / \mathrm{k} . \mathrm{b} . \mathrm{wt} / \mathrm{day}$.

Regarding the kidney histopathology study, the results showed that EG caused crystal deposits in the tubules, dilatation of the collecting tubules, necrosis of the tubular epithelium, inflammation, edema, and congestion of interstitium (Figure 2). Interestingly, BPE and cystone treatment markedly prevented these histological changes observed in the EG-treated groups.

\section{Antioxidant activity assays and Phenolic constituents}

BPE showed an important antioxidant capacity towards the DPPH, ABTS and ferric reducing power $(0.72 \pm 0.031 \mathrm{mg} / \mathrm{ml}, 0.16 \pm 0.04 \mathrm{mg} / \mathrm{ml}$ and $0.12 \pm 0.087 \mathrm{mg} / \mathrm{ml}$ respectively $)$ but these values were significantly $(P<0.05)$ lower than BHT $(0.021 \pm 0.01 \mathrm{mg} / \mathrm{ml})$, the Gallic acid $(0.019 \pm 0.001 \mathrm{mg} / \mathrm{ml})$ and the ascorbic acid $(0.03 \pm 0.07 \mathrm{mg} / \mathrm{ml})$. The amount of phenols in BPE was $51.35 \pm 2.61 \mathrm{mg} \mathrm{GAE} / \mathrm{gram}$, flavonoids content was $1.87 \pm 0.06 \mathrm{mg} \mathrm{QE} / \mathrm{gram}$ and total antioxidant capacity was $234.53 \pm 2.63 \mathrm{mg} \mathrm{AAE} / \mathrm{gram}$.

\section{Discussion}

The effects of EG demonstrated in the present study are similar to its reported impacts elsewhere [3, 25]. EG increases urine calcium, phosphate, uric acid, proteins, and oxalate in rats [26]. Another study showed that EG causes renal damage by increasing the serum concentration of creatinine, uric acid, and proteins [27].

Treatment with BPE or cystone increases urine volume. The diuretic activity of BPE might be due to the significant increase in urine sodium and chloride excretion. BPE decreased potassium excretion compared to the control group. Therefore, BPE has a considerable diuretic 
activity with a potassium-sparing effect. The increase in the urine excretion decreases urine solute concentration and ultimately reduces saturation and stone formation. Thiazide diuretics, which are part of stone management, reduce urinary supersaturation because of their diuretic and hypocalciuric action [28]. We have found that honey and propolis contain polyphenols and cause a significant diuresis [29]. Studies showed that flavonoids possess diuretic effects $[30,31]$. This effect might help to explain the diuretic activity of BPE. EG also causes an increase in urinary volume. The use of BPE with EG causes a further increment in the urinary volume.

BPE causes increased serum protein in EG untreated group, most likely due to its nutritional content. EG caused increase serum protein, which might be due to inflammatory reaction and tissue damage caused by EG. However, BPE mitigates hyperproteinemia caused by EG, which is likely by its antioxidant and anti-inflammatory activity. Further studies are needed to explore the mechanism of action.

The present study showed that BPE significantly decreases urine calcium and phosphate levels, which presumably helps prevent stone formation. An increase in the urine phosphorus and calcium excretion was observed in the EG-treated rats, which leads to the generation of calcium phosphate crystals. The oxalate presence provides a suitable environment for stone formation where the calcium phosphate induces calcium oxalate deposition [32,33]. Therefore, BPE might reduce stone formation by increasing urine volume and decreasing urine calcium, phosphate, and oxalate crystals, which was evident by the direct microscopic examination of the urine. It was found that magnesium is a well-known inhibitor of calcium oxalate crystallization, and it can reduce the precipitation potential [34, 35]. In the present experiment, EG decreases urine magnesium that was increased by administration of BPE or cystone. In earlier observation, we have found that propolis, which is another bee product, also alleviated EG-induced urinary depletion of magnesium [3].

The administration of EG significantly decreases urine volume, which might be the result of renal impairment. It was found that EG causes AKI due to proximal tubular cell necrosis that results from several metabolites (glycolaldehyde, glyoxylate, glycolate, and oxalate) and deposition of calcium oxalate monohydrate crystals inside the lumen of kidney tubules [36]. In the present study, AKI was evident by a significant elevation of the serum creatinine and blood urea levels observed after EG administration. BPE significantly reduces blood urea and serum creatinine levels and therefore prevents EG-induced AKI. Proteinuria reflects proximal tubular dysfunction, and it is common in AKI. Interestingly, BPE significantly decreased protein excretion, and thus it might have the potential to prevent the nidus formation for crystal nucleation. This finding is similar to our previous finding that showed propolis's ability to decrease protein excretion caused by EG administration [3].

EG increased serum levels of liver enzymes (ALT, AST, GGT, and ALP), which have been normalized by ingestion of BPE or cystone. The effect was most likely due to anti-inflammatory and antioxidant properties [37].

The maximum BPE effect that mitigates the risk factor for stone formation and crystallization and prevention of AKI and liver injury was noted at a dose of $500 \mathrm{mg} / \mathrm{kg} . b . w t$ per day compared with 100 and $250 \mathrm{mg} / \mathrm{kg} . b . w t$ per day. The mechanism underlying this effect is most likely mediated by antioxidant compounds present in BPE and their antioxidant activity. The data presented herein showed that BPE possesses potent antioxidant activity against DPPH, ABTS, and ferric reducing power. Furthermore, BPE contains a high quantity of phenols and flavonoids. The result is similar to previously published papers [38, 39]. Calcium oxalate stimulates the production of reactive oxygen species and inflammation, and antioxidants' administration protects against nephrolithiasis [40]. It was found that EG causes oxidative stress that was mitigated by antioxidant, catechin [41].

Studies showed that flavonoids possess diuretic effects, and phenols and flavonoids alleviate AKI, renal fibrosis, and inflammation [30, 31, 42]. These findings might partly explain the BPE protective effect mechanism against EG-induced AKI, proteinuria, and crystalluria. Further studies are currently in progress in our laboratory to explore in-depth the mechanism of action.

In conclusion, BPE possesses significant nephroprotective, anti-urolithiasis, and hepatoprotective activities, which were evident by its ability to decrease urine calcium, phosphate, protein, uric acid, and crystals, and to increase urine volume and urine magnesium. Interestingly, it prevented $\mathrm{AKI}$ and acute liver injury by decreasing blood urea, creatinine, liver enzymes and increasing urine creatinine and urea and creatinine clearance. Also, it ameliorated EG-induced histopathological changes and crystal deposition in the kidney tissue. The mechanism of action is unknown, but its antioxidant activity and its content of flavonoids and flavones might play a role in its activity. Further studies are required to elicit the mechanism of the action and test BPE in the other kidney diseases that cause proteinuria caused by other medical conditions such as diabetes and AKI management. These studies will pave the way for clinical studies.

\section{Methods}

\section{Collection and Extraction of fresh bee pollen}

Page 9/15 
Fresh bee pollen was obtained from beehives located in Sidi kacem, west of Morocco, and was directly stored at $-20^{\circ} \mathrm{C}$. The sample was then extracted by maceration at ambient temperature for one week in ethanol 70\% under agitation, then filtered through a Whatman filter paper [43]. The alcohol was removed by vacuum rotary evaporation at $60^{\circ} \mathrm{C}$, then dried at the same temperature. The extract obtained was stored at $-20^{\circ} \mathrm{C}$ until analysis. Distilled water was added to get three different concentrations $(100,250$, and $500 \mathrm{mg} / \mathrm{kg} \mathrm{b}$.wt) given to the animals daily by gavage.

\section{Experimental Animals}

Adult male Wistar rats (200-220 g) were obtained from the Animal Housing Breeding Center, Department of Biology, Faculty of Sciences,

Fes, Morocco and were used for the experiments. Animals were housed under standard environmental conditions $\left(25 \pm 1^{\circ} \mathrm{C}\right.$ and 12 hours/ 12 hours light/dark cycle) and were maintained with free access to water and laboratory rat chow. Ethical approval was obtained from Sidi Mohamed Ben Abdallah University Mohammed in Fez, the Animal Facility, and the Laboratory of Physiology-Pharmacology \& Environmental Health, the Faculty of Science Dhar Mahraz, Fez (01DEC2016). The experiments were conducted following the internationally accepted principles for the care and use of laboratory animals. All efforts were made to minimize animal suffering and the number of animals used. The study was carried out in compliance with the ARRIVE guidelines (http://www.nc3rs.org.uk/page.asp? id=1357).

\section{Experimental Groups}

Sixty animals were randomly divided into ten groups as Group I-10: containing six animals each.

Group 1; served as a vehicle untreated control and maintained regular rat food and drinking water ad libitum.

Group 2; received cystone (500 mg/kg body weight).

Group 3; received BPE (100/mg/kg. b. wt).

Group 4; received BPE (250/mg/kg. b. wt).

Group 5; received BPE (500/mg/kg. b. wt).

Group 6; received $0.75 \%$ v/v EG in drinking water.

Groups 7-9; received $0.75 \%$ v/v EG + BPE at a dose of 100, 250 and $500 \mathrm{mg} / \mathrm{kg}$. b.wt per day respectively.

Group 10; received $0.75 \%$ v/v EG + cystone (500 mg/kg.b.wt per day).

BPE and cystone were administrated daily by gavage for a total of 30 days. The dose of cystone was $500 \mathrm{mg} / \mathrm{kg}$, according to previous studies $[44,45]$. According to previous publications, the management's duration was 30 days, which used 28-30 days [44-46]. Ethylene glycol $(0.75 \%)$ in drinking water was used $[43,46]$. The animals drunk the water containing $E G$, and this was monitored as each animal was housed in a metabolic cage with free access to food and drinking water with EG in a graduated bottle.

\section{Collection and analysis of urine samples}

Each animal was kept in an individual metabolic cage, and the urine was collected on days 0,15 , and 30 of the study periods. The animals had free access to food and drinking water during the urine collection period. The urine was analyzed for volume, $\mathrm{pH}$, calcium, inorganic phosphorus, magnesium, electrolytes, urea, creatinine, and total proteins.

\section{Urinary Crystal Study}

Urine was collected from all groups after 30 days of the experiment, and microscopic examination was performed to identify urinary crystals.

\section{Blood analysis}

On day 30 of the experiment, all the rats were subjected to anesthesia (diethyl ether), and the blood was collected from the retro-orbital sinus puncture. The serum was separated by centrifugation at $10,000 \mathrm{~g}$ for 10 minutes, and analysis of creatinine, urea, sodium, potassium, magnesium, calcium, phosphate, and total proteins were performed. Hepatic function was evaluated by measuring serum alkaline 
phosphatase (ALP), alanine aminotransferase (ALT), Gamma glutamyl-transferase (GGT), and aspartate aminotransferase (AST). All the analyses were performed by Architect c8000 analyzer using two methods potentiometry and spectrophotometry.

\section{Kidney histopathology}

The animals were sacrificed under anesthesia, and the kidney was removed, cleaned off extraneous tissue and rinsed in ice-cold physiological saline. The kidney was fixed in $10 \%$ neutral buffered formalin, processed in a series of graded alcohol and xylene, embedded in paraffin wax, sectioned at $5 \mu \mathrm{m}$, and stained with Hematoxylin and Eosin for histopathological examination. The slides were examined under a light microscope to study the kidney and calcium oxalate deposits' architecture. The kidneys of each rat were studied for the histopathological process. Many slides were performed, and the clearest ones were studies and pictured. The images were processed with GIMP software to increase the clearness.

\section{Determination of total phenolic content}

Total phenol in the bee pollen solution was determined by the Foline Ciocalteu colorimetric method, according to Ahn et al. [47]. Fifty $\mu \mathrm{L}$ of BPE solution was mixed with $250 \mu \mathrm{L}$ of the Folin-Ciocalteu reagent $(0.2 \mathrm{~N})$ and $200 \mu \mathrm{L}$ of $(75 \mathrm{~g} / \mathrm{L}) \mathrm{Na} 2 \mathrm{CO}$, and the absorbance was measured at $760 \mathrm{~nm}$ after 2 hours of incubation at room temperature. The experiment was done in triplicates, and the results were expressed as mean \pm SD mg equivalent of gallic acid/gram bee pollen.

\section{Total flavonoid content}

The flavonoid content was quantified according to the method described by Miguel et al. [48]. Briefly, $200 \mu \mathrm{l} 2 \%$ AlCl3 was added to $50 \mu \mathrm{l}$ of BPE or standard. After 1 hour at room temperature, the absorbance was measured at $420 \mathrm{~nm}$. Quercetin was used as standard, and flavonoid content was expressed as mg quercetin equivalents per gram BPE (mg QE/g). The tests were performed in triplicate, and the results were expressed as mean \pm SD.

\section{Total antioxidant capacity}

The total antioxidant capacity in BPE solution was determined according to the ammonium molybdate colorimetric method of Prieto et al. [49]. Briefly, $1 \mathrm{ml}$ of reagent solution ( $0.6 \mathrm{M}$ sulfuric acid, $28 \mathrm{mM}$ sodium phosphate, and four $\mathrm{mM}$ ammonium molybdate) was added to 50 $\mu \mathrm{l}$ of BPE. The mixture was capped and incubated in a thermal block at $95^{\circ} \mathrm{C}$ for 1 hour and 30 minutes. The absorbance of the reaction mixture was measured at $700 \mathrm{~nm}$ against a blank. Ascorbic acid was used as the standard calibration, and the results were expressed as milligrams of Ascorbic acid equivalent per gram of BPE.

\section{Free radical scavenging activity on DPPH}

The radical scavenging activity of BPE solution against2,2-diphenyl-1-picrylhydrazyl (DPPH) free radical was measured [50]. Fifty $\mu \mathrm{L}$ of BPE solution was added to $825 \mu \mathrm{L}$ of ethanolic solution of DPPH. Absorbance measurements were read at $517 \mathrm{~nm}$ after 20 minutes of incubation time at room temperature; (A1) Absorption of a blank sample containing water instead of BPE, and (A0) DPPH solution acted as the negative control. The percentage of inhibition was calculated using the formula: [(A0-A1/A0) $\left.{ }^{1} 100\right]$, and $I C_{50}$ was determined. The tests were repeated in triplicate, and the results are given as the mean \pm SD.

\section{Reducing power (FRAP)}

The reducing power was determined according to the method described by Moreira et al. [51]. The BPE solution (50 $\mu \mathrm{L})$ was mixed with 200 $\mu \mathrm{L}$ of $0.2 \mathrm{M}$ sodium phosphate buffer ( $\mathrm{pH} 6.6)$ and $200 \mu \mathrm{L}$ of $1 \%$ potassium ferricyanide. The mixture was incubated at $50^{\circ} \mathrm{C}$ for 20 minutes, and $200 \mu \mathrm{L}$ of $10 \%$ trichloroacetic acid, $200 \mu \mathrm{L}$ of distilled water, and $120 \mu \mathrm{L}$ of $0.1 \%$ of ferric chloride were added. The mixture absorbance was measured at $700 \mathrm{~nm}$. Extract concentration providing 0.5 of absorbance $\left(\mathrm{EC}_{50}\right)$ was calculated from the absorbance graph against extract concentration in the solution. Ascorbic acid was used as a positive control. The tests were repeated in triplicate, and the results were expressed as mean \pm SD.

\section{Scavenging Activity Of Abts Radical Cation}

The ABTS radical cation (ABTS+) scavenging activity was measured according to the method described by Miguel et al. [52]. Briefly, the ABTS+ radical was generated by the reaction of $(7 \mathrm{mM})$ ABTS aqueous solution with $\mathrm{K} 2 \mathrm{~S} 208(2.45 \mathrm{mM})$ in the dark for 16 hours and adjusting the Absorbance at $734 \mathrm{~nm}$ to 0.7 at room temperature. BPE solution $(50 \mu \mathrm{L})$ was added to $(825 \mu \mathrm{L}) \mathrm{ABTS}+$ solution, and the absorbance was measured at $734 \mathrm{~nm} 5$ minutes after the initial mixing, using water as the blank. Several concentrations were made, and the percentage inhibition [(A0-A1/A0)*100] was plotted against phenol content, and $\mathrm{IC}_{50}$ was determined (concentration of BPE able to scavenger $50 \%$ of $A B T S+$ free radical).

Page $11 / 15$ 


\section{Statistical analysis}

The results were expressed as mean \pm standard deviation. The statistical significance was assessed using one-way analysis of variance (ANOVA) followed by post hoc Tukey's Multiple Comparison Test using Graph Pad Prism 5 software.

\section{Declarations}

\section{Conflict of interest}

The authors declare no competing interests.

\section{Ethics approval and consent to participate}

Not applicable

\section{Consent for publication}

Not applicable

\section{Availability of data and material}

Not applicable

\section{Funding}

Not applicable

\section{Authors' contributions}

All authors contributed significantly to the concept of research, conduction of experiment, preparation and publications of the paper

\section{Acknowledgements}

Not applicable

\section{References}

1. Mulay SR, Kulkarni OP, Rupanagudi KV, Migliorini A, Darisipudi MN, Vilaysane A. Calcium oxalate crystals induce renal inflammation by NLRP3-mediated IL-1 $\beta$ secretion. J Clin Invest. 2013; 123: 236-246

2. Mulay SR, Desai J, Kumar SV, Eberhard JN, Thomasova D, Romoli S. Cytotoxicity of crystals involves RIPK3-MLKL-mediated necroptosis. Nat Commun. 2016;7: 10274

3- El Menyiy N, Al Waili N, Bakour M. Protective Effect of Propolis in Proteinuria, Crystaluria, Nephrotoxicity and Hepatotoxicity Induced by Ethylene Glycol Ingestion. Arch Med Res. 2016;47(7):526-534.

4. Alkahtani S, Sammons H, Choonara I. Epidemics of acute renal failure in children (diethylene glycol toxicity). Arch Dis Child. 2010 Dec;95(12):1062-4.

5. Patocka J, Hon Z. Ethylene glycol, hazardous substance in the household.

.Acta Medica (Hradec Kralove). 2010;53(1):19-23.

6. Ratkalkar VN, Kleinman JG. Mechanisms of stone formation. Clin Rev Bone Miner Metab. 2011;9(3-4):187-197.

7. Khan SR. Calcium oxalate crystal interaction with renal tubular epithelium, mechanism of crystal adhesion and its impact on stone development. Urol Res. 1995;23(2):71-79.

8. Bhasin B, Ürekli HM, Atta MG. Primary and secondary hyperoxaluria: Understanding the enigma. World J Nephrol 2015;4(2):235-244. 
9. Sorokin I, Pearle MS. Medical therapy for nephrolithiasis: State of the art. Asian J Urol. 2018;5(4):243-255.

10. Porter H. Ethylene glycol poisoning: quintessential clinical toxicology; analytical conundrum. Clin Chim Acta. $2012: 413$ (3); $365-377$.

11. Yao H, Wang X, Wang D, Shi A, Xu X, Yang Z, Li Z. Investigation on injury of liver and kidney among the workers exposed to terephthalic acid, ethylene glycoland (or) dowtherm A. Zhonghua Lao Dong Wei Sheng Zhi Ye Bing Za Zhi. $2002 ; 20$ (1):5-9.

12. Giner T, Ojinaga V, Neu N, Koessler M, Cortina G. Ethylene glycol intoxication presenting with high anion gap metabolic acidosis, acute kidney injury and elevated lactate. Pediatr Int. 2018;60(2):194-195.

13. Ares AM, Valverde S, Bernal JL. Extraction and determination of bioactive compounds from bee pollen. J Pharm Biomed Anal 2018;147:110-124.

14.Denisow B, Denisow-Pietrzyk M. Biological and therapeutic properties of bee pollen: a review. J Sci Food Agric. 2016;96(13):4303-4309.

15. Mitra S, Gopumadhavan S, Venkatarangannna M, Sundaram R. Effect of cystone, a herbal formulation, on glycolic acid-induced urolithiasis in rats. Phytother Res .1998;12(5): 372-374

16. Palaniyamma D, Jeyaraman R. Evaluation of Efficacy and Safety of a Herbal Formulation Cystone Forte in the Management of Urolithiasis. J Urol Res. 217; 4(4): 1093.

17. El-Ghiaty MA, Ibrahim OM, Abdou SM, Hussein FZ. Evaluation of the protective effect of Cystone ${ }^{\circledR}$ against cisplatin-induced nephrotoxicity in cancer patients, and its influence on cisplatin antitumor activity. Int Urol Nephrol. $2014 ; 46$ (10):1367-73.

18. Takawale R, Mali V, Kapase C, Bodhankar S. Effect of Lagenaria siceraria fruit powder on sodium oxalate induced urolithiasis in Wistar rats. J Ayurveda Integr Med. 2012;3(2):75-9.

19. Bodakhe K, Pnamdeo K, Patra K. A polyherbal formulation attenuates hyperoxaluria-induced oxidative stress and prevents subsequent deposition of calcium oxalate crystals and renal cell injury in rat kidneys. Chinese J Natural Med.2013;11(3): 466-471

20. Rao M, Praveen Rao PN, Kamath R, Rao MN. Reduction of cisplatin-induced nephrotoxicity by cystone, a polyherbal ayurvedic preparation, in C57BL/6J mice bearing B16F1 melanoma without reducing its antitumor activity. J Ethnopharmacol. $1999 ; 68: 77-81$.

21. Karamakar D, Patki P. Evaluation of efficacy and safety of a herbal formulation Cystone in the management of urolithiasis: Metaanalysis of 50 clinical studies. The Internet J Altern Med. 2008; 8 (1). https://print.ispub.com/api/0/ispub-article/8636.

22. Randhawa R, Bhardwaj R, Kaur T. Amelioration of hyperoxaluria-induced kidney dysfunction by chemical chaperone 4-phenylbutyric acid. Urolithiasis. 2019 Apr;47(2):171-179.

23. Ahmed S, Hasan MM, Khan H. The mechanistic insight of polyphenols in calcium oxalate urolithiasis mitigation. Biomed Pharmacother. 2018;106:1292-1299.

24. Maruyama H, Sakamoto T, Araki Y, Hara H. Anti-inflammatory effect of bee pollen ethanol extract from Cistus sp. of Spanish on carrageenan-induced rat hind paw edema. BMC Complement Altern Med. 2010;10:30-30

25. Tyl RW, Price CJ, Marr MC. Developmental toxicity evaluation of ethylene glycol by gavage in New Zealand white rabbits. Fundam Appl Toxicol. 1993;20(4):402-412.

26. Shah JG, Patel BG, Patel SB. Antiurolithiatic and antioxidant activity of Hordeum vulgare seeds on ethylene glycol-induced urolithiasis in rats. Indian J Pharmacol. 2012;44(6):672-677.

27. Ashok P, Koti BC, Vishwanathswamy AHM. Antiurolithiatic and antioxidant activity of Mimusops elengi on ethylene glycol-induced urolithiasis in rats. Indian J Pharmacol. 2010 Dec;42(6):380-383.

28. Bergsland KJ, Worcester EM, Coe FL. Role of proximal tubule in the hypocalciuric response to thiazide of patients with idiopathic hypercalciuria. Am J Physiol Renal Physiol. 2013;305(4):F592-599.

29. El-Guendouz S, Al-Waili N, Aazza S, Elamine Y, Zizi S, Al-Waili T, Al-Waili A, Lyoussi B. Antioxidant and diuretic activity of coadministration of Capparis spinosa honey and propolis in comparison to furosemide. Asian Pac J Trop Med. 2017 Oct;10(10):974-980

Page 13/15 
30. Jouad H, Lacaille-Dubois M, Lyoussi B, Eddouks M. Effects of the flavonoids extracted from Spergularia purpurea Pers. on arterial blood pressure and renal function in normal and hypertensive rats. J Ethnopharmacol. 2001; 76 (2): $159-163$

31. Wu J, Muir A. Isoflavone content and its potential contribution to the antihypertensive activity in soy bean angiotensin I converting enzyme inhibitory peptides. J Agric Food Chem. 2008; 56 (21): 9899-9904

32. Balaji KC, Menon M. Mechanism of stone formation. Urol Clin North Am. 1997;24(1):1-11.

33. Evan AP. Physiopathology and etiology of stone formation in the kidney and the urinary tract. Pediatr Nephrol Berl Ger. 2010;25(5):831841.

34. Tavasoli S, Taheri M, Taheri F, Basiri A, Bagheri Amiri F. Evaluating the associations between urinary excretion of magnesium and that of other components in calcium stone-forming patients. Int Urol Nephrol. 2019;51(2):279-284

35. Das P, Gupta G, Velu V, Awasthi R, Dua K, Malipeddi H. Formation of struvite urinary stones and approaches towards the inhibition-A review. Biomed Pharmacother. 2017;96:361-370.

36. Seo JW, Lee JH, Son IS, Kim YJ, Kim DY, Hwang Y, Chung HA, Choi HS, Lim SD. Acute oxalate nephropathy caused by ethylene glycol poisoning. Kidney Res Clin Pract. 2012;31(4):249-252

37. Jin T-Y, Saravanakumar K, Wang M-H. In vitro and in vivo antioxidant properties of water and methanol extracts of linden bee pollen. Biocatal Agric Biotechnol. 2018;13 (2):186-189.

38. Taha E-KA, Al-Kahtani S, Taha R. Protein content and amino acids composition of bee-pollens from major floral sources in Al-Ahsa, eastern Saudi Arabia. Saudi J Biol Sci. 2019;26(2):232-237.

39. Kalaycıoğlu Z, Kaygusuz H, Döker S. Characterization of Turkish honeybee pollens by principal component analysis based on their individual organic acids, sugars, minerals, and antioxidant activities. LWT. 2017;84 (3):402-408.

40. Joshi S, Khan S. Opportunities for future therapeutic interventions for hyperoxaluria: targeting oxidative stress. Expert Opin Ther Targets. 2019 May;23(5):379-391.

41. Zhai W, Zheng J, Yao X, Peng B, Liu M, Huang J. Catechin prevents the calcium oxalate monohydrate induced renal calcium crystallization in NRK-52E cells and the ethylene glycol induced renal stone formation in rat. BMC Complement Altern Med. 2013 Sep $17 ; 13: 228$.

42. Yu W, Quan F, Cao Q, Lin Y, Yue C, Bi R, Cui X, Yang H, Yang Y, Birnbaumer L, Li X, Gao X. Quercetin alleviates acute kidney injury by inhibiting ferroptosis. J Adv Res. 2020 Jul 22;28:231-243

43. Bakour M, Al-Waili NS, El Menyiy N, Imtara H, Figuira AC, Al-Waili T. Antioxidant activity and protective effect of bee bread (honey and pollen) in aluminum-induced anemia, elevation of inflammatory makers and hepato-renal toxicity. J Food Sci Technol.

2017;54(13):4205-4212

44. Das M, Malipeddi H. Antiurolithiatic activity of ethanol leaf extract of Ipomoea eriocarpa against ethylene glycol-induced urolithiasis in male Wistar rats. Indian J Pharmacol. 2016;48(3):270-4.

45. Mitra S. Gopumadhavan S, Venkataranganna M, Sundaram R. Effect of cystone, a herbal formulation, on glycolic acid-induced urolithiasis in rats. Phytotherapy Res. 1998;12(3): 372-374

46. Jarald E, Kushwah P, Edwin S, Asghar S, Patni S.Effect of Unex on ethylene glycol-induced urolithiasis in rats. Indian J Pharmacol. 2011 ; 43(4): 466-468.

47. Ahn MR, Kumazawa S, Usui Y. Antioxidant activity and constituents of propolis collected in various areas of China. Food Chem. 2015; 101(4):1383-1392.

48. Miguel M da G, Nunes S, Dandlen SA. Phenols and antioxidant activity of hydro-alcoholic extracts of propolis from Algarve, South of Portugal. Food Chem Toxicol. 2010;48(12):3418-3423. 
49. Prieto P, Pineda M, Aguilar M. Spectrophotometric quantitation of antioxidant capacity through the formation of a phosphomolybdenum complex: specific application to the determination of vitamin E. Anal Biochem. 1999;269(2):337-341.

50. Kumazawa S, Hamasaka T, Nakayama T. Antioxidant activity of propolis of various geographic origins. Food Chem. 2004 ;84(3):329339.

51. Moreira L, Dias LG, Pereira JA. Antioxidant properties, total phenols and pollen analysis of propolis samples from Portugal. Food Chem Toxicol. 2008;46(11):3482-3485.

52. Miguel M da G, Doughmi O, Aazza S. Antioxidant, anti-inflammatory and acetylcholinesterase inhibitory activities of propolis from different regions of Morocco. Food Sci Biotechnol. 2014;23(1):313-322.

\section{Figures}

\section{Figure 1}

Light microscopic examination of the urine samples collected seen under microscope at $10 \times 10 \mathrm{X}$ magnification at the end of the 30-d control and treatment period showing multiple crystals in EG treated group. A; Control group; B: Cystone treated group; C: Bee pollen treated group $100 \mathrm{mg}$; D: Bee pollen treated group $250 \mathrm{mg}$; E: Bee pollen treated group $500 \mathrm{mg}$; F: EG treated group; G: EG+ Cystone treated group; H: EG+ Bee pollen treated group $100 \mathrm{mg}$; I: EG+ Bee pollen treated group $250 \mathrm{mg}$; J: EG+ Bee pollen treated group $500 \mathrm{mg}$.
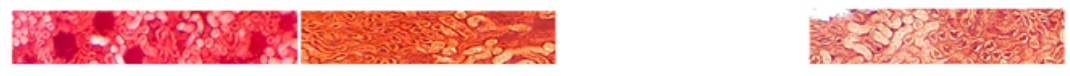

\section{Figure 2}

Histopathological examination of Kidney slides of different treatment groups seen under microscope at $10 \times 10 \mathrm{X}$ magnification. A; Control group; B: Cystone treated group; C: Bee pollen treated group $100 \mathrm{mg}$; D: Bee pollen treated group $250 \mathrm{mg}$; E: Bee pollen treated group 500 mg; F: EG treated group; G: EG+ Cystone treated group; H: EG+ Bee pollen treated group $100 \mathrm{mg}$; l: EG+ Bee pollen treated group $250 \mathrm{mg} ; \mathrm{J}$ : $\mathrm{EG}+$ Bee pollen treated $500 \mathrm{mg}$. 